\title{
Regulation of Nanorefrigerant Use: A Proactive Measure Against Possible Undesirable Health and Environmental Implications
}

\author{
Nnamdi V. Ogueke1*, Nwabueze Emekwuru² \\ ${ }^{1}$ Mechanical Engineering Department Federal University of Technology PMB 1526, Owerri, Nigeria \\ ${ }^{2}$ Faculty of Engineering, Environment and Computing School of Mechanical, Automotive and Aerospace Engineering \\ Coventry University, Coventry UK
}

*Corresponding Author: nvogueke@futo.edu.ng

Citation: Ogueke, N.V. and Emekwuru, N. (2017). Regulation of Nanorefrigerant Use: A Proactive Measure Against Possible Undesirable Health and Environmental Implications. European Journal of Sustainable Development Research, 1(2), 09.

doi: $10.20897 /$ ejosdr.201709

Published: June 30, 2017

\begin{abstract}
Recent research studies have shown the very high potentials nanotechnology application has in the refrigeration and air conditioning industry for improving the thermophysical properties of refrigerants and lubricants hence leading to systems with higher COP and much reduced size. The successes achieved with nanorefrigerants are connected to the improved technology for the preparation of nanofluids that has led to achieving more homogeneous and stable mixture of the base fluid and nanoparticle. However, available literatures point to the fact that nanoparticles can find its way into the human cells and as such is a potential health risk for humans and animals. At present, emphasis appears to concentrate more on the technological successes achieved with nanorefrigerants, like improved thermal conductivity, nucleate boiling and boiling heat transfer coefficient without factoring in much the potential health implications of adopting it. This paper therefore looked at the potential health consequences of adopting nanotechnology and called for an early regulatory framework to guard against any unforeseen health issues. Areas of future research were also suggested.
\end{abstract}

Keywords: nanorefrigerant, nanolubricant, regulation, health, environmental

\section{INTRODUCTION}

Nanotechnology can be viewed as the concept of employing particles in the atomic and molecular order to enhance the performance of a system. These particles are called nanoparticles and have diameters in the range of $1 \mathrm{~nm}-100 \mathrm{~nm}$ (Salamanca-Buentello et al, 2005). The enhancement could be achieved by "doping" the working fluid or some of the materials of this system with the nanoparticles thereby enhancing their thermophysical properties. The concept and ideologies behind the application of nanoparticles can be traced to the lecture delivered by Richard Feynman in December 1959 at the American Physical Society Meeting. However, it was not until the 1980s that the science of nanotechnology (as it is known today) fully emerged and in the early 2000, its awareness began to grow. This growing awareness led to the lunching of initiatives by countries to increase their capacities in nanotechnology. One of such is the National Nanotechnology Initiative (NNI), established in 2001 by the US Government which involves 20 Federal departments, independent agencies, and commissions all working towards further evolving the application of nanotechnology (NNI, 2015). Other such national initiatives include the Nanomaterials Science and Technology Initiative in India, South African Nanotechnology Initiative 
Table 1. Major initiatives, centers, institutes, or government organizations working towards nanotechnology development.

\begin{tabular}{|c|c|c|}
\hline $\begin{array}{l}\text { Country or } \\
\text { district }\end{array}$ & Initiatives, centers, institutes or government organizations & Links \\
\hline USA & $\begin{array}{l}\text { National Nanotech Initiative (NNI) } \\
\text { Food and Drug Administration (FDA) } \\
\text { Environmental Protection Adm inistration (EPA) } \\
\text { Center for Nanotechnology } \\
\text { National Science Foundation } \\
\text { Project on Emerging Nanotechnologies }\end{array}$ & $\begin{array}{l}\text { http://www.nano.gov } \\
\text { http://www.fda.gov/nanotechnology } \\
\text { http://es.epa.gov/ncer/nano } \\
\text { http://www.ipt.arc. nasa.gov/index.html } \\
\text { http://www.nsf.gov/crssprgm/nano } \\
\text { http://www.nanotechproject.org }\end{array}$ \\
\hline European Union & $\begin{array}{l}\text { Community Research \& Development } \\
\text { Information Service (CORDIS) } \\
\text { European Nanotechnology Gateway } \\
\text { European Nanobusiness Association (ENA) }\end{array}$ & $\begin{array}{l}\text { http://cordis.europa.eu/nanotechnology } \\
\text { http://www.nanoforum.org } \\
\text { http://www.nanoeurope.org }\end{array}$ \\
\hline UK & $\begin{array}{l}\text { Institute of Nanotechnology (loN) } \\
\text { The Royal Society and Royal Academy of Engineering } \\
\text { Health and Safety Executive (HSE) } \\
\text { Institute of Food Science and Technology (IFST) } \\
\text { Department for Environment, Food and } \\
\text { Rural Affa irs (Defra) }\end{array}$ & $\begin{array}{l}\text { http://www.nano.org.uk } \\
\text { http://www.royalsoc.ac.uk/page.asp?id=1212 } \\
\text { http//wwww.hse.gov.uk/horizons/nanotech/index.htm } \\
\text { http://www.ifst.org } \\
\text { http://www.defra.gov.uk/environment/nanotech/index.htm }\end{array}$ \\
\hline France & $\begin{array}{l}\text { Ministry for Research and New Technology } \\
\text { French Research Network in Micro and Nano } \\
\text { Technologies (RMNT) } \\
\text { Centre National de la Recherche Scientifique } \\
\text { (National Center for Scientific Research) (CNRS) }\end{array}$ & $\begin{array}{l}\text { http://www.nanomicro.recherche gouv. fr/uk_index.html } \\
\text { http://www.rmnt.org/EN/index.html } \\
\text { http://www.cnrs.fr/index.html }\end{array}$ \\
\hline Germany & $\begin{array}{l}\text { German Federal Institute for Risk Assessment (BfR) } \\
\text { Federal Ministry of Education and Research (BMBF) }\end{array}$ & $\begin{array}{l}\text { http://wwww.bfr.bund.de/cd/template/index_en } \\
\text { http://www.bmbf.de/en/nanotechnologie.php }\end{array}$ \\
\hline Italy & $\begin{array}{l}\text { National Institute for the Physics of Matter (INFM) } \\
\text { Association italiana per la ricerca industriale (AIRI) }\end{array}$ & $\begin{array}{l}\text { http://www.infm.it/ } \\
\text { http://www.airi.it/2005/index.php }\end{array}$ \\
\hline Canada & National Institute for Nanotechnology & http://nint-innt.nrc-cnrc.gc.ca/home/index_e. html \\
\hline Japan & $\begin{array}{l}\text { Nanotechnology Researchers Network Center (Nanonet) } \\
\text { National Food Research Institute (NFRI) } \\
\text { RIKEN } \\
\text { Japan Society for the Promotion of Science (JSPS) } \\
\text { Ministry of Education, Culture, Sports, Science } \\
\text { and Technology (MEXT) } \\
\text { National Institute of Health Sciences (NIHS) } \\
\text { National Institute for Environmental Studies (NIES) } \\
\text { National Institute of Advanced Industrial Science } \\
\text { and Technology (AIST) } \\
\text { National Institute for Materials Science (NIMS) } \\
\text { Ministry of Economy, Trade and Industries (METI) }\end{array}$ & $\begin{array}{l}\text { http://www.nanonet.go.jp/english } \\
\text { http://www.nfri.affrc.go.jp/english/ourroles/index.html } \\
\text { http//wwww.rikenresearch.riken.jp } \\
\text { http://www.jsps.go.jp/english/index.html } \\
\text { http://www.mext.go.jp/english } \\
\text { http://www.nihs.go.jp/index.html } \\
\text { http://www.nies.go.jp/index.html } \\
\text { http://www.aist.go.jp/index_en.html } \\
\text { http://www.nims.go.jp/eng/index.html } \\
\text { http://www.meti.go.jp/english }\end{array}$ \\
\hline China & $\begin{array}{l}\text { Chinese Academy of Sciences } \\
\text { National Center for Nanoscience and Technology (NCNST) } \\
\text { Key Laboratory of Molecule Nanostructure and } \\
\text { Nanotechnology, Chinese Academy of Sciences }\end{array}$ & $\begin{array}{l}\text { http: } / / \text { wwww.cas.ac.cn/Index/OC/Index.htm } \\
\text { http://www.nanoctr.cn/e_index.jsp } \\
\text { http } / / \text { wwww.icas.ac.cr } 5 \text { __keyanxitong/stm/english/home.htm }\end{array}$ \\
\hline Taiwan & $\begin{array}{l}\text { Industrial Technology Research Institute (ITRI) } \\
\text { NanoTechnology Research Center (NTRC) } \\
\text { nanoMark } \\
\text { National Nano Device Laboratories (NDL) } \\
\text { National Science and Technology Program for } \\
\text { Nanoscience and Nanotechnology }\end{array}$ & $\begin{array}{l}\text { http } / / \text { wwww.itri.org.tw/eng/research/nano/index.jsp } \\
\text { http://www.ntrc. itri.org.tw/eng/index.jsp } \\
\text { http://www.nanomark.itri.org.tw/Eng } \\
\text { http://www.ndl.org.tw } \\
\text { http://nano-taiwan.sinica.edu.tw/newsen.asp }\end{array}$ \\
\hline Korea & $\begin{array}{l}\text { Korean Food \& Drug Administration (KFDA) } \\
\text { National Nanofab Center (NNFC) } \\
\text { Korea Institute of Science and Technology Information (KIST) } \\
\text { Center for Nanostructured Materials and Technology (CNMT) } \\
\text { National Center for Nanomaterials Technology (NCNT) }\end{array}$ & $\begin{array}{l}\text { http: } / / \text { wwww.kfda.go.kr } \\
\text { http://www.nnfc.com/index.html } \\
\text { http://www.kisti.re.kr } \\
\text { http://cnmt.kist.re.kr } \\
\text { http://www.nano.or.kr/english/index.asp }\end{array}$ \\
\hline Australia & $\begin{array}{l}\text { CSIRO Manufacturing and Materials Technology (CMMT) } \\
\text { Department of Industry, Tourism and Resources (ITR) } \\
\text { Nanostructural Analysis Network Orga nisation, Major National } \\
\text { Research Facility (NANO-MNRF) }\end{array}$ & $\begin{array}{l}\text { http://www.cmit.csiro.au/brochures/tech/nanotech } \\
\text { http://www.industry.gov.au/nano } \\
\text { http://www.nano.org.au }\end{array}$ \\
\hline
\end{tabular}

and Iran Nanotechnology Initiative Council. Table 1 shows the major initiatives, centers, institutes, or government organizations working towards nanotechnology development (Chau et al, 2007).

These initiatives have in no small way contributed to the progress so far made in the application nanotechnology in different spheres of life. This can be seen from the high number of patents recorded in nanotechnology applications. For instance, the number of patents in nanotechnology in the European Patent Office (EPO) has been on the increase since 2001. It rose from 776 in 2001 to 4622 in 2013 [Statnano: http://www.statnano.com/news/45696 (accessed: May 24, 2016)]. Figure 1 shows the patent trend from 1991 2013 while Figure 2 shows the journal publications on nanotechnology for the same period.

Nanotechnology has a wide range of applications covering engineering, ICT, agriculture and the medical sciences. In its application for comfort and the preservation of agricultural products and vaccines, the emphasis appears to be in applying nanoparticles to improve the coefficient of performance (COP) or cooling power of refrigeration and air conditioning machines. This has given rise to what today is called Nanorefrigerants and 


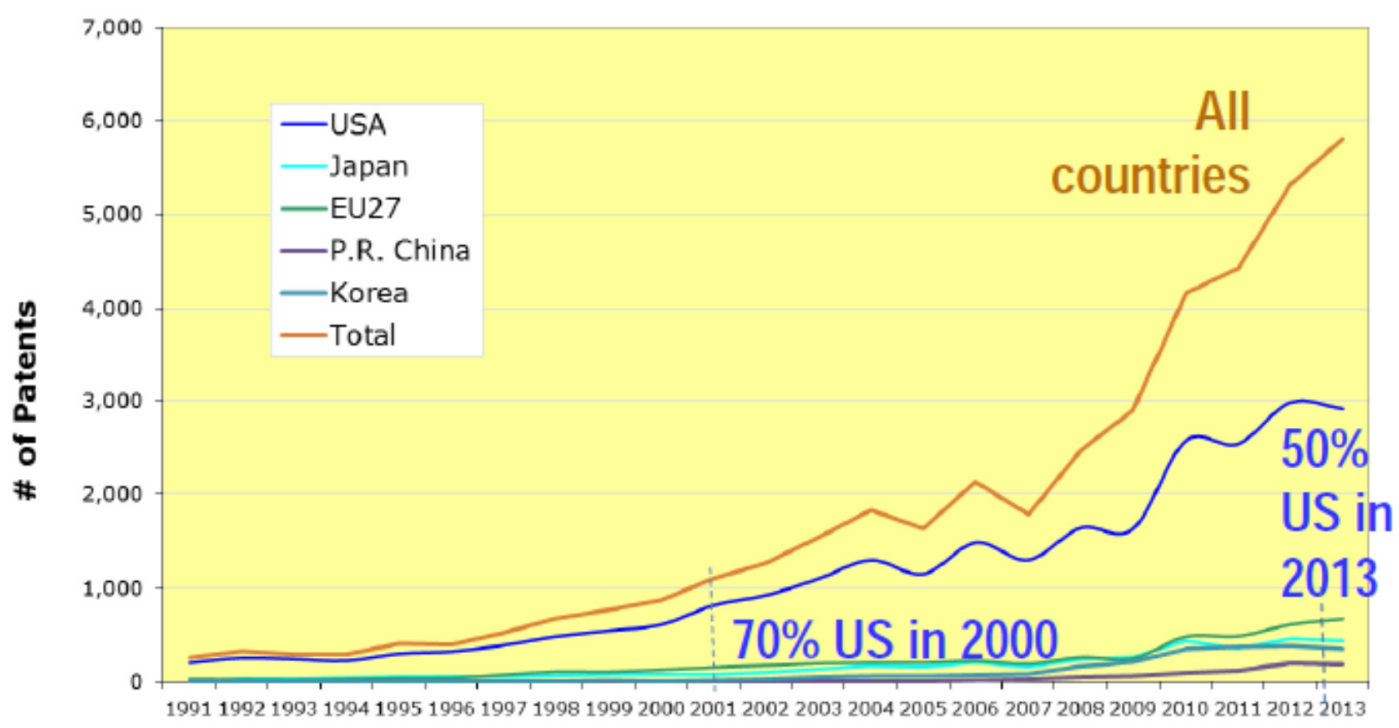

Figure 1. Patents recorded between 1991 and 2013 (Source: Roco, 2014).

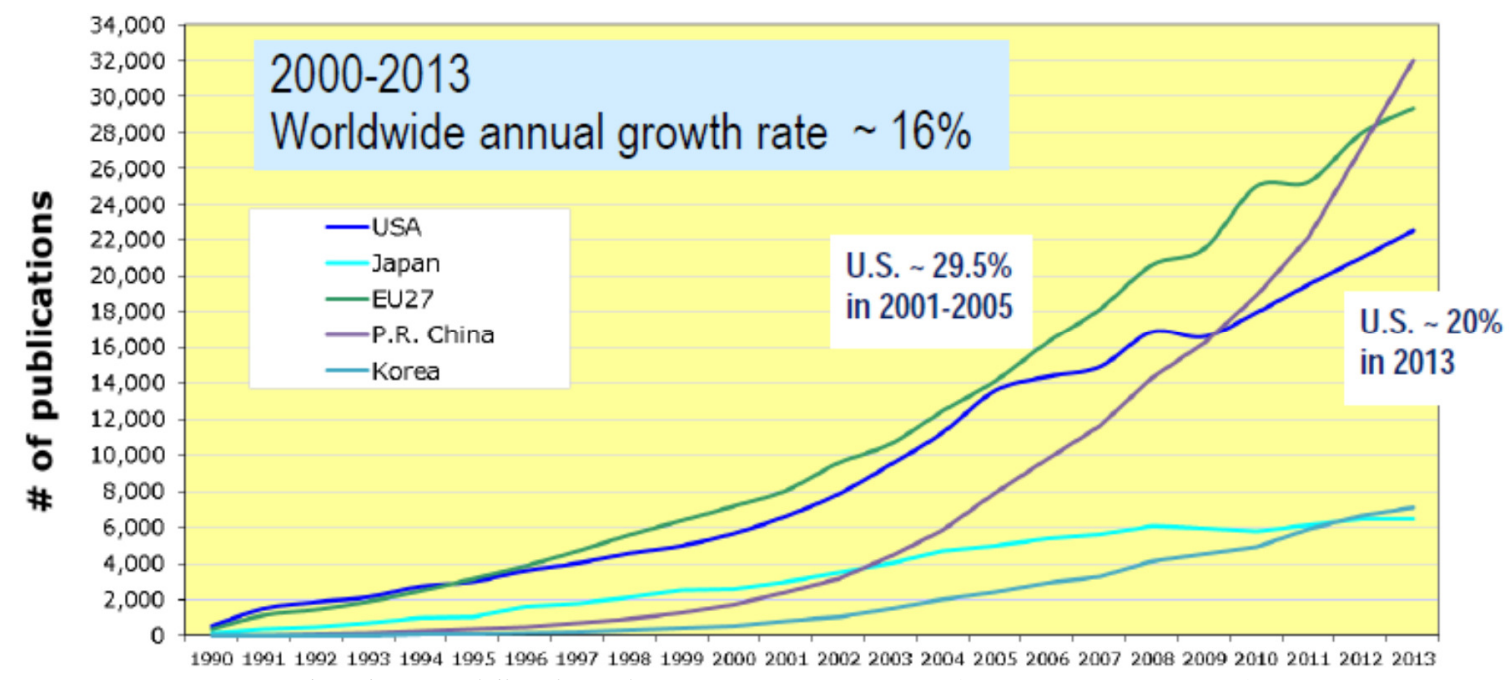

Figure 2. Nanotechnology publications between 1991 - 2013 (Source: Roco, 2014)

Nanolubricants formed by suspending nanoparticles in a base fluid (which in this case is a conventional refrigerant like R-134a and conventional compressor oil).

Several studies have been reported on the successes achieved by using nanorefrigerants as the working fluid of a refrigerating system. These successes boarder on improved system COP, reduced power consumption and better heat transfer between the working fluid and the air that requires cooling. Some of these works are those by Subramani and Prakash (2011), Jiang et al (2009), Yang et al (2015), Akhavan-Behabadi et al (2015), Bi et al (2011), Yang et al (2012) and Coumaressin and Palaniradja (2014). Apart from nanorefrigerants, nanolubricants can be used to increase thermal dissipation, reduce wear and mitigate some extreme pressure characteristics of compressors lubricants as seen from the works of Subramani and Prakash (2011) and Subramani et al (2013).

While these works have gone a long way to establishing the very high benefits of using nanorefrigerants and nanolubricants, little or nothing has been reported on investigation of the possible medical effects of applying nanotechnology in the refrigeration industry. This is important in order to begin early to work out ways of mitigating their possible undesirable medical and environmental effects. Therefore, in this work, we aim to use some known information about nanoparticles to project the possible medical and environmental effects of their use in the refrigeration industry, review current laws/regulations guiding their use and make case for the early establishment of laws/regulation in the absence of any. 


\section{PREPARATION OF NANOREFRIGERANTS AND THERMAL IMPROVEMENTS ACHIEVED}

Series of studies have been reported on nanorefrigerants. They are basically a mixture of the pure conventional refrigerant and nanoparticles, with the conventional refrigerant acting as the base fluid. Two basic methods exist for their preparation: the one-step and two-steps methods. While the one-step method involves the simultaneous production and dispersion of nanoparticles in the base fluid, the two-steps method requires that the nanoparticles be generated first by any of the industrial methods followed by its dispersion in the base fluid. Although different methods of nanofluid production have been tested, however, in general, a homogeneous and stable mixture of the base fluid and the nanoparticle is achieved by stirring using a magnetic stirrer and subsequent homogenization using an ultrasonic homogenizer. To avoid agglomeration and hence ensure more stable mixture, surfactants are used. This way, the nanorefrigerant will possess thermophysical properties different from that of the base fluid. Reported works point to different levels of thermophysical properties enhancement, depending on the nanoparticle used and the base fluid/nanoparticle ratio. Jiang et al (2009) recorded a 104\% enhancement in thermal conductivity over that of a base fluid of R113 by introducing Carbon Nanotubes (CNT) nanoparticle, Peng et al (2010) experimented with nanorefrigerant produced from R113 and CNT and observed an increase of $61 \%$ in nucleate boiling, Sun and Yang (2013) reported an increase of $17-25 \%$ and 3-20\% respectively for maximum heat transfer coefficient and average heat transfer coefficient values while testing nanorefrigerants produced from R141b and $\mathrm{Cu}, \mathrm{Al}$, Aluminum Oxide $\left(\mathrm{Al}_{2} \mathrm{O}_{3}\right)$ and Cupper Oxide $(\mathrm{CuO})$ while Henderson et al (2010) recorded over 100\% increase in boiling heat transfer coefficient with nanorefrigerant produced from $\mathrm{R} 134 \mathrm{a}$ and $\mathrm{CuO}$. While these may not be the only thermophysical properties of concern for a refrigerant, studies have shown that they are all reasonably affected (either positively or negatively) by the addition of nanoparticles to the base refrigerant. A detailed review of this has been done by Nair et al (2016).

\section{NANOPARTICLES: SIZE AND POTENTIAL HEALTH EFFECTS}

Nanoparticles are very small, with size in the range of about $1 \mathrm{~nm}$ to about $100 \mathrm{~nm}$ (one-billionth of a meter) (Salamanca-Buentello, 2005). This means that they are not visible, since visible particles have size of $10-13$ micrometer (i.e. one-millionth of a meter) or more (https://www.coloradoci.com/bin-pdf/5270/ParticleSize.pdf Accesses: May 30, 2016). Settling time of particles in the atmosphere greatly depends on their sizes, with the larger sized ones settling faster than their smaller counterparts. For instance, particles larger than $100 \mu \mathrm{m}$ have sedimentation velocity greater than $0.5 \mathrm{~m} / \mathrm{s}$ thus they settle quickly. Those in the range $1-100 \mu \mathrm{m}$ have sedimentation velocity greater than $0.2 \mathrm{~m} / \mathrm{s}$ and less than $0.5 \mathrm{~m} / \mathrm{s}$ while those less than $1 \mu \mathrm{m}$ fall slowly and take days to years to settle out of a quiet atmosphere (Air Filtration Systems. Available from: http://www.afslasvegas.com/ParticleSizes.html Accessed: May 30, 2016). Thus, when nanoparticles get into the atmosphere, there are higher chances that they may remain suspended until removed by some artificial means. Suspended particles in the atmosphere have been shown to have various medical consequences. For instance, many lung infections have been attributed to the prolonged inhalation of cement dust (Noor et al, 2000) while asthmatic patients usually have their conditions aggravated in environments with high level of suspended particulate matters. Nanoparticles by having sizes of $1-100 \mathrm{~nm}(0.001-1 \mu \mathrm{m})$ therefore could have the same or even higher health risk factor when their concentration level increases in the atmosphere. This is because at that size, they fall within the range of particles not easily screened out in the human respiratory system and as such find their way into the human cell. Figure 3 (National Institute of Environmental Health Sciences Community Outreach and Education Programme. Particles: "Size Makes All the Difference". Available from: http://www.niehs.nih.gov/health/assets/docs a e/ehp student edition lesson particles size makes all the difference.pdf :accessed on May 30,2016) shows the common particle, their sizes and how easily they are inhaled. It can be seen from this figure that nanoparticles fall in the range of particles that get deep into the lungs. In fact, particles less than $100 \mathrm{~nm}(0.1 \mu \mathrm{m})$ can be absorbed into the body and distributed to the cells (Environews, 2005). Since these are metals foreign to the body cells, there is a high likelihood that once in the body system, they will likely affect the proper functioning of the system. Figure 4 [https://www.coloradoci.com/binpdf/5270/ParticleSize.pdf (accesses: May 30, 2016)] shows that nanoparticles are likely to have similar penetration effect in our body as Carbon Black.

Apart from the figures, some studies have shown that the use of nanoparticles could be quite harmful. Tsuji et al (2006) found that carbon nanotubes apparently have greater pulmonary toxicity (inflammation, granuloma) in mice than fine-scale carbon graphite. Kim et al (2003) pointed out that nanoparticles, when inhaled, may accumulate in the lungs and cause chronic diseases like pneumonia, pulmonary inflation, pulmonary granuloma, and oxidative stress. This has also been corroborated by Nel et al (2006). When deposited on the skin, nanoparticles 


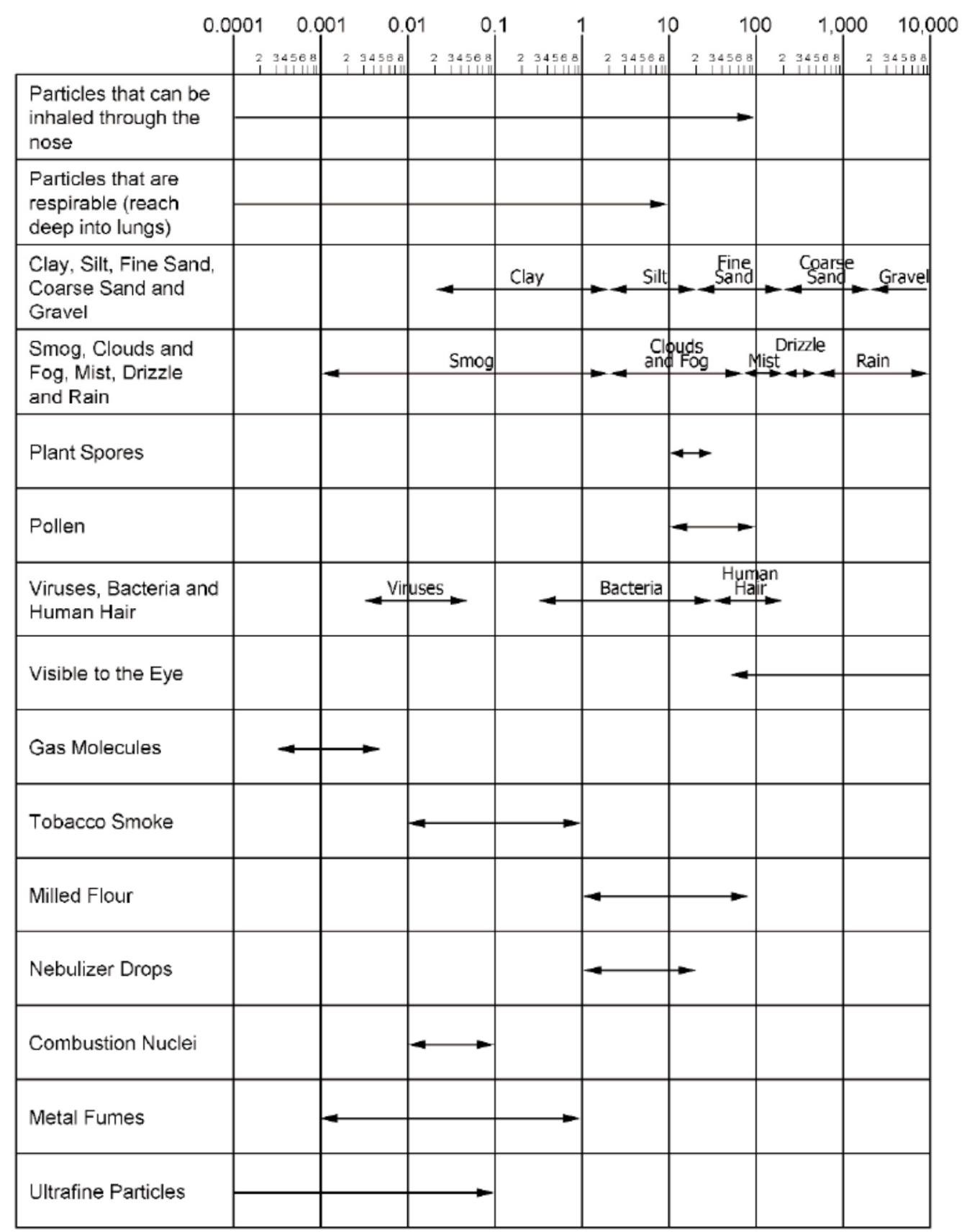

Figure 3. Particle size distribution in micrometer $(1 \mu \mathrm{m}=1000 \mathrm{~nm})$

could find its way into the dermis and then move through the lymph to the regional lymph nodes (Oberdörster et al., 2005) while some, in particular, small titanium dioxide particles (about $20 \mathrm{~nm}$ ), could penetrate through the skin and interact with the immune system (Kreilgaard, 2002). Titanium dioxide and zinc oxide, through the effect of light, could generate hydroxyl radicals which may bring about oxidative damage in skin (Wakefield et al, 2004). Gibbs and Tang (2004) listed some ten (10) works pointing to the highly toxic nature of most nanoparticles while Sweet and Strohm (2006) summarizes what is currently known regarding the potential toxicity and hazards of nanomaterials. All these therefore point to the fact that nanotechnology could lead to very serious environmental and health challenges.

\section{REVIEW OF POTENTIAL HEALTH IMPLICATION OF NANOTECHNOLOGY USE IN THE ENERGY SECTOR}

Application potentials of nanotechnology appears limitless and the energy sector is therefore not an exception. Some of the potential areas in the energy sector can be grouped into Energy sources (e.g. Photovoltaics, Wind Energy and Nuclear), Energy change (e.g. Gas Turbine and Combustion Engines), Energy distribution (e.g. High Voltage Transmission, Super Conductors and CNT Power Lines), Energy storage (e.g. Batteries, Phase Change 


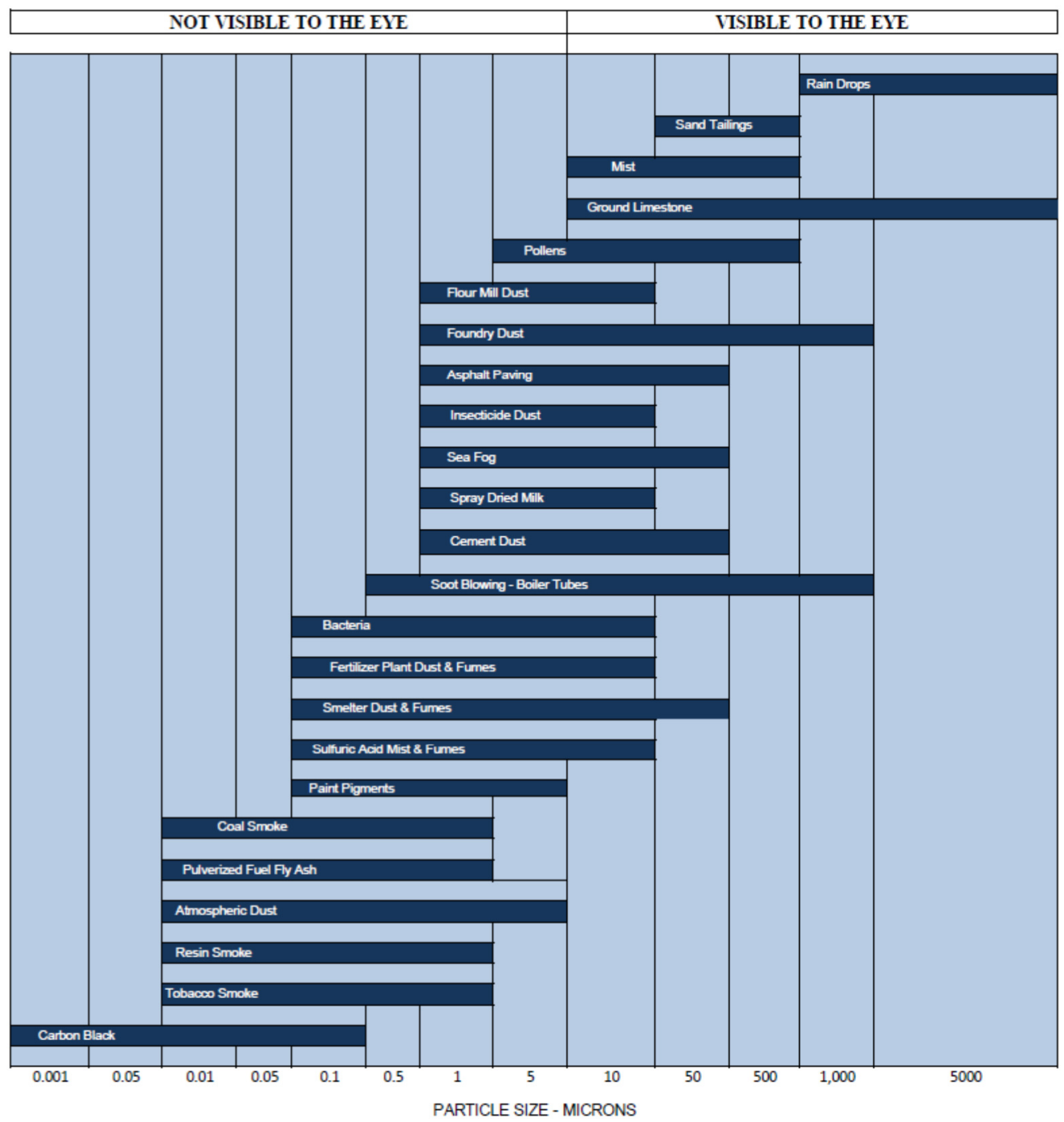

Figure 4. Particle size chart $(1 \mu \mathrm{m}=1000 \mathrm{~nm})$

Materials and Supercapacitors) and Energy usage (e.g. Refrigeration and Air Conditioning, Thermal Insulation and Lighting). At present, no explicit record of health or environmental consequence of their application in this sector has been reported. However, reports of various medical consequences of different nanoparticles used in the energy sector exist. Some of these nanoparticles are Carbon Nanotubes (CNT), Aluminum Oxide $\left(\mathrm{Al}_{2} \mathrm{O}_{3}\right)$, Cupper Oxide $(\mathrm{CuO})$, Titanium dioxide $\left(\mathrm{TiO}_{2}\right)$ and Quantum Dots. Their potential for causing harm depends on shape, surface charge, mass, surface area, aspect ratio (the ratio of width to height of an object), crystal structure, stability, and distributions in size and degree of dispersion of the particles (Christian et al, 2008). This implies that production method of and the use a nanoparticle is put to, where it is located and what form it takes in the product will highly influence its toxicology potentials.

$\mathrm{CNT}$ is one of the most commonly used in the energy sector. Some of this type of nanoparticles have been shown to behave like asbestos fibres by causing "length dependent inflammation qualitatively and quantitatively similar to the foreign body inflammatory response caused by long asbestos" (Poland et al, 2008), a fact that was confirmed by preliminary research results released by NIOSH (National Institute for Occupational Health and Safety, USA) in March 2009 (Senjen, 2009). Because exposure to nanotubes can occur at all stages of its production (Gustavsson et al, 2011), its health implication may be quite significant. Table 2 (Senjen, 2009) shows summary of some key health effects of CNT.

Nanoparticles of $\mathrm{Al}_{2} \mathrm{O}_{3}, \mathrm{CuO}, \mathrm{TiO}_{2}$ and Quantum dot also used in the energy sector have been variously reported to have either medical or environment effect or both. For instance, quantum dot can break down in the human body potentially causing cadmium poisoning while $\mathrm{TiO}_{2}$ have been found to cause free radicals in skin cells, damaging DNA (Gibbs and Tang, 2004). Also, $\mathrm{TiO}_{2}$ promote photocatalytically initiated, free-radical degradation of prepainted steel sheets installed in roofing applications (Barker and Branch, 2008) and affect the degradation and stabilization of polymers and coatings (Allen et al, 2004). $\mathrm{Al}_{2} \mathrm{O}_{3}$, according to studies by Chen et al (2008), kills cells that line the blood vessel in human brain while Arul et al (2011) concluded that $\mathrm{Al}_{2} \mathrm{O}_{3}$ is generally toxic to normal cell line. On plants, Yanik and Vardar (2015) found that $\mathrm{Al}_{2} \mathrm{O}_{3}$ lead to phytotoxicity in wheat roots culminating in morphological, cellular and molecular alterations. Similarly, Burklew et al (2012) found 
Table 2. Summary of some key health effects of nanotubes.

\begin{tabular}{|c|c|c|}
\hline $\begin{array}{l}\text { Type of Carbon } \\
\text { Nanotube } \\
\end{array}$ & Cell type or Species & Effects \\
\hline SWCNT & $\begin{array}{l}\text { Human embryo kidney exposed to } 0.78- \\
200 \mathrm{mg} / \mathrm{mL} \text { for up to } 5 \text { days }\end{array}$ & $\begin{array}{l}\text { Dose-and time dependent inhibition of cell } \\
\text { proliferation, and a decrease in cell adhesive } \\
\text { ability }\end{array}$ \\
\hline $\begin{array}{l}\text { SWCNT (unrefined, } \\
30 \% \text { iron) }\end{array}$ & $\begin{array}{l}\text { Human skin cells exposed to } 0.6-0.24 \\
\mathrm{mg} / \mathrm{mL} \text { after } 2 \text { to } 18 \text { hours in }\end{array}$ & $\begin{array}{l}\text { Oxidative stress, involved in many diseases, } \\
\text { such as atherosclerosis, Parkinson's disease, } \\
\text { Heart Failure, Alzheimer's disease }\end{array}$ \\
\hline SWCNT (various) & Human skin cells & $\begin{array}{l}\text { Cytotoxicity dependent on the density of } \\
\text { surface functionalisation }\end{array}$ \\
\hline SWCNT & $\begin{array}{l}\text { Mice exposed to concentrations between } \\
0 \text { and } 0.5 \mathrm{mg} \text { in during } 7 \text { and } 90 \text { days }\end{array}$ & $\begin{array}{l}\text { Dose-dependent granulomas and interstitial } \\
\text { inflammation }\end{array}$ \\
\hline MWCNT & $\begin{array}{l}\text { Intratracheal exposure of mice to a } \\
\text { single dose of } 1,2.5 \text {, or } 5 \mathrm{mg} / \mathrm{kg}\end{array}$ & Pulmonary effects, then death \\
\hline $\begin{array}{l}\text { MWCNT } \\
\text { various diameters, } \\
\text { lengths, shape and } \\
\text { chemical composition }\end{array}$ & $\begin{array}{l}\text { Mice lungs injected with } 50 \mathrm{mg} \\
\text { MWCNT for } 24 \text { hours or } 7 \text { days }\end{array}$ & Significant increase in inflammation \\
\hline MWCNT & $\begin{array}{l}\text { Asthmatic and non-asthmatic mice were } \\
\text { exposed to a MWCNT aerosol (100 } \\
\mathrm{mg} / \mathrm{m} 3) \text { for } 6 \text { hours }\end{array}$ & $\begin{array}{l}\text { Asthmatic mice responded with airway } \\
\text { fibrosis }\end{array}$ \\
\hline
\end{tabular}

that $\mathrm{Al}_{2} \mathrm{O}_{3}$ nanoparticles have a negative effect on the growth and development of tobacco seedling leading to an overall reduction in the root length. Boyles et al (2016) found that $\mathrm{CuO}$ nanoparticles lead to proinflammatory conditions, oxidative stress and programmed cell death accompanied by a significant alteration of cells metabolic activity. Karlsson et al (2008) showed that $\mathrm{CuO}$ nanoparticles have very high cytotoxicity and DNA damage potential. Interestingly, most of the studies on medical or environmental effects of these nanoparticles appear to infer that the effects of nanoparticles of these metals were more lethal than their natural form.

\section{A TYPICAL REFRIGERATION CYCLE}

$\mathrm{CNT}, \mathrm{Al}_{2} \mathrm{O}_{3}, \mathrm{CuO}, \mathrm{TiO}_{2}$ are the major nanoparticles that have been successfully used to achieve significant improvement in the thermophysical properties of refrigerants and compressor lubricants. Therefore, there is a great need for caution in the use of their nanorefrigerants and nanolubricants.

The vapour compression refrigeration system (VCS) where these nanorefrigerants have been and will continue to be applied is a closed system. Figure 5 shows the schematic diagram of a typical VCS. The low temperature and pressure refrigerant in the liquid phase evaporates in the evaporator. In the compressor, it is compressed and sent to the condenser where it loses heat and returns to liquid state, though this time, at high temperature and pressure. This high temperature and pressure liquid refrigerant is throttled to low pressure and temperature and returned to the evaporator for the cycle to be repeated. Cooling is achieved during the evaporation process. While during operation there is no direct contact between the refrigerant and the environment, a leak in any of the system components lets out the refrigerant into the environment. Refrigerant leak is a common problem in refrigerating system, and this is often not noticed until most of the refrigerant leaks out and the systems performance reduces significantly. If the leak occurred in any of the refrigerating system component within the space being cooled, there will be higher likelihood of the nanoparticle being inhaled, if it is for space cooling for comfort. The bigger the refrigerating system capacity, the more the refrigerant and thus more nanoparticle will be discharged during a leak.

Apart from the exposure to nanoparticles during refrigerant leak while the cooling system is in operation, another area with high potential of contact or discharge into the environment is during the preparation of the nanorefrigerant/nanolubricant. This is obvious from the method of preparation detailed in Alawi et al (2014) and Yang et al (2012), which will require getting a specified mass of nanoparticle and mixing it with a known volume of the host fluid (refrigerant). Alawi et al (2014) observed that preparation of nanorefrigerants when the host fluid is in liquid state at room temperature and atmospheric pressure, is easier than when they are in vapour state at room temperature and atmospheric pressure. Such cases will most likely lead to more nanoparticle contact or discharge to the environment during preparation. Unfortunately, most refrigerants are vapour at room temperature and atmospheric pressure. Nanorefrigerant stability is another sensitive aspect. If its stability is not fully guaranteed 


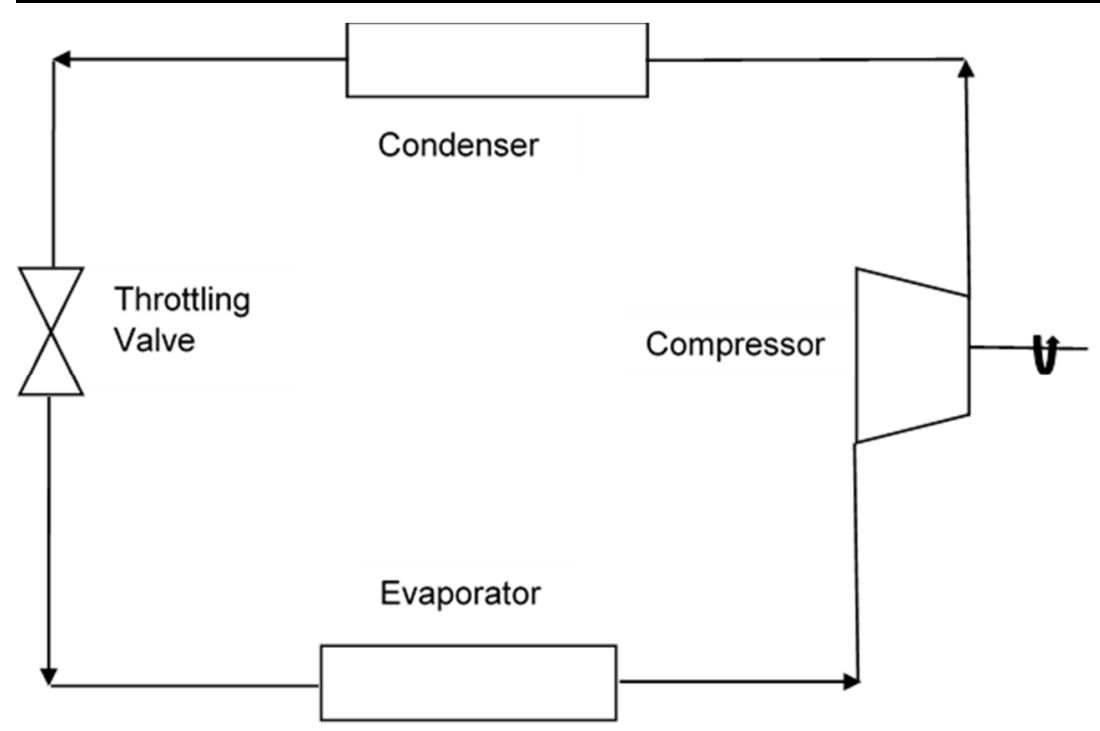

Figure 5. Schematic diagram of a typical VCS

during operation life of the cooling system, then there will be high frequency of refrigerant replacement and subsequent disposal which, depending on the disposal approach may result in higher rate of nanoparticles discharge to the environment. Unfortunately, their long-term stability, negligible agglomeration without affecting their thermophysical properties is still a challenge as noted by Sidik et al (2014).

\section{USE OF NANOREFRIGERANTS: ANY REGULATIONS?}

Maxwell (1873) was the first to attempt dispersing solid particles in a fluid as a way of enhancing its thermophysical properties. However, it was not until 1995 that S. Choi successfully dispersed nanoparticles in fluid and subsequently called it nanofluid (Nair et al, 2016). When the base fluid is any of the conventional refrigerants, it is referred to as nanorefrigerant while it is nanolubricant when used to enhance the performance of any traditional lubricant applied in the refrigeration industry. The general aim of the application of nanorefrigerant and nanolubricant is captured by Nair et al (2016) as (i) leading to smaller and lighter refrigeration systems and (ii) consumption of less compressor power (i.e. higher energy efficiency). Considering the level of success reported on the application of nanorefrigerants, it will not be long before it gains wide acceptability. This will lead to the production of new cooling systems running on the nanorefrigerants and nanolubricants while there will be increased efforts to retrofit existing ones. This calls for proper regulations.

There is significant debate on whether nanotechnology based products require specific government regulation. For instance, the EU organization Strategy for Nanotechnology believes it has the potential to enhance quality of life and industrial competitiveness. Hence they are pushing for minimal legislation (Soliman, 2012). In the USA, a 2007 report of the U.S. Food and Drug Administration's Nanotechnology Task Force 33 concluded that no further regulation is needed for nanomaterials, a report jointly opposed by the environmental group, Friends of the Earth, and the International Center for Technology Assessment. In 2014, FDA gave a set of guidance (which they described as Nonbinding Recommendations) to industries on the application of nanotechnology. However, considering the wide range of nanotechnology application, a regulatory framework is required to contend with entirely new challenges their full deployment may introduce. That probably explains why it was recommended that under the chemical safety regulations such as Notification of New Substances (NONS) and Registration, Evaluation, and Authorization Chemicals (REACH), nanoparticles or nanotubes should be treated as new substances (HSE, 2006; The Royal Society, 2004). Since the main aim of REACH is that new chemicals should not be allowed into the market without convincing safety data, it then will also apply to nanoparticles.

Generally, regulatory system the world over assesses the health and safety of new substances and products on a case-by-case basis. Hence nanoparticles use in the refrigeration industry should be assessed based on the peculiarities of the refrigeration and heat pump equipment. A review of the existing guidelines in the refrigeration industry reveals that there is no regulation currently applying to nanorefrigerant or nanolubricants use. Countries at present appear to rely on existing regulations which has no explicit reference to nanotechnology. Some of these regulations are those dealing with the harmful chemicals, fire risk, and explosion risk of materials as contained in the Control of Substances Hazardous to Health Regulations (COSHH), guidance on COSHH risk assessments, ACOP from the Dangerous Substances and Explosive Atmosphere Regulations (DSEAR), and guidance of precautions against the explosion risk of combustible dusts, (HSE, 2004; HSE, 2006; IFST, 2006; Chau, 2007). 


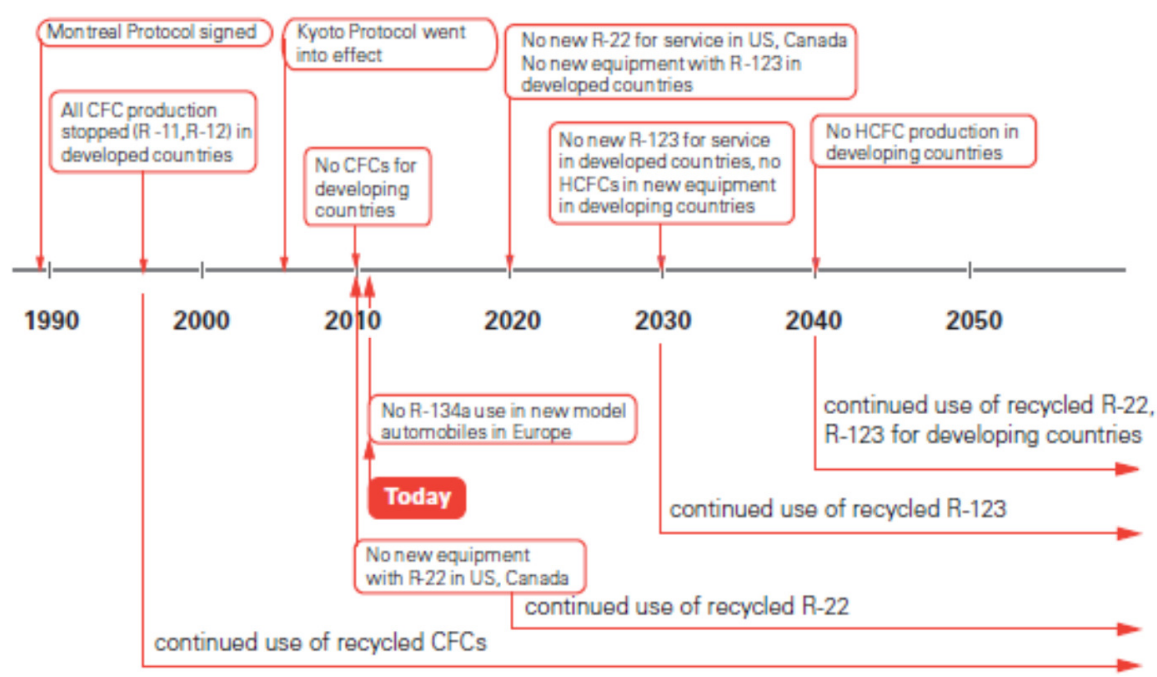

Figure 6. Major actions involving refrigerants in the developed and developing countries

Because of the non-explicit mention of nanoparticles, there is a possibility of untested nanotechnology based substances slipping through cracks of those regulations. However, chemicals, cosmetics and food industry have identified the need for adequate regulation of nanotechnology in the areas through Regulation (EC) No 1223/2009 which specifically refers to nanomaterials and offers the first legal definition. It specifies among others that specific information like physicochemical specifications, toxicological profile, safety assessment and exposure conditions must be reported on these nano based products six months before as well as including the nano-ingredients in the list of ingredients (Cushen et al, 2012). Even though the definition did not consider soluble or physiologically unstable nanoscale systems from the nanomaterial specific notification requirements, it is a positive step towards proper regulation of nanomaterials which should be adopted by the other sector, especially the refrigeration industry.

\section{REVIEW OF EXISTING REGRIGERANTS REGULATIONS}

Regulation of refrigerants in the refrigeration industry could be traced back to the 1930s when the earlier refrigerants, like sulfur dioxide, methyl chloride and ammonia were replaced by the chlorofluorocarbon (CFC) refrigerants because of concerns about hazards posed by their toxicity and high flammability potential. By the 1970s, environmental concerns resulting from the depletion of ozone layer gave rise to the Montreal Protocol, which established phase-out dates for the use and production of ozone-depleting substances. This led to the CFCs being replaced by the Hydrochlorofluorocarbons (HCFCs) and Hydrofluorocarbons (HFCs) with low and zero ozone depletion potential (ODP), respectively. Beginning from 1987 when the protocol took effect, a final phaseout date was put at 1996, for CFCs, and 2030 (2040 in developing countries) for HCFCs (Moe et al, 2011). Montreal Protocol concentrated more on combating ozone depletion substances hence, in 1997 the Kyoto Protocol was created to address another environmental concern, Global Warming. The Kyoto Protocol set target for greenhouse gas, including HFCs, reduction in developed countries. Figure 6 (Moe et al, 2011) shows a summary of the major actions involving refrigerants in the developed and developing countries. The F-Gas regulation of 2015 (EIA, 2015) aims at the containment and recovery of certain F-gases in the EU. Under the regulation, it is illegal to use disposable refrigerant cylinders and requires the labeling of all HFC refrigerant cylinders and systems. There are also very strict and rigid rules for monitoring of all equipment with potential leakage of fluorinated refrigerants to atmosphere. For instance, any refrigerating/air conditioning equipment containing $3 \mathrm{~kg}$ or above of refrigerant should be checked for leakage every 12 months while those containing $30 \mathrm{~kg}$ must be checked every six months (except if an automatic leak detector is installed) and those with $300 \mathrm{~kg}$ or more must have an automatic leak detector as well as physically checking them every six months. Furthermore, the maintenance record must be well kept and the servicing technician properly identified in the building operator's records. In the United States of America, the US Clean Air Act, section 608, makes it illegal to knowingly discharge refrigerants into the atmosphere as shown in Figure 7 (EPA, 430-F-10-040). To ensure compliance, defaulter could be fined as much as $\$ 37,500.00$ per day by EPA for any violation of the regulations. 


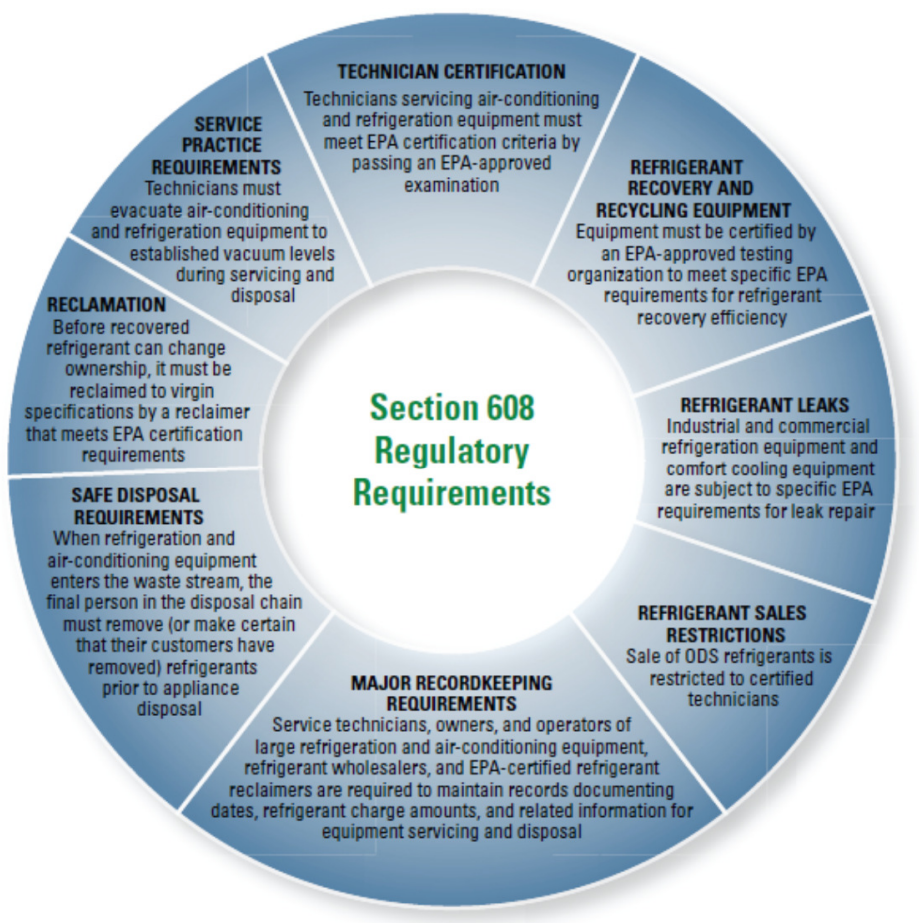

Figure 7. Stationary Refrigeration and Air Conditioning Regulatory Requirements

\section{THE NEED FOR NANOREGRIGERANT USE REGULATIONS}

The environmental and medical consequences of any technology depend greatly on its use. Refrigeration and heat pump accounts for a large percent of the energy used in residential and industrial buildings and this may likely increase as condition of living continues to improve. This implies that the use of nanorefrigerants will also continue to increase. Since these are fluids formed by the addition of nanoparticles to known refrigerants, it implies that production and usage of nanoparticles will increase. Already, refrigerants in their present form have their undesirable environmental consequences, thus increasing the use of nanorefrigerants may further increase the undesirable environmental and health consequences of refrigeration and heat pumps, more especially considering that different nanoparticles exist and each may interact or react distinctly with the host fluid (refrigerant or lubricant) and may have its own distinct environmental or medical consequences. The world is still battling to mitigate effects of earlier unregulated use of the CFCs in refrigeration industry. While these effects affected the environment directly and subsequently health, the nanorefrigerants unregulated use have the tendency of directly impacting health and the environment; a fact that can be inferred from the works of Poland et al (2008), Senjen (2009), Gibbs and Tang (2004), Chen et al (2008), Arul et al (2011), Yanik and Vardar (2015), Burklew et al (2012), Boyles et al (2016), Karlsson et al (2008), Barker and Branch (2008), Allen et al (2004), Kim et al (2003), Nel et al (2006), Oberdörster et al. (2005), Kreilgaard (2002), Wakefield et al (2004), Gibbs et al (2004) and Sweet and Strohm (2006). With nanoparticles finding their way into human, animal cells and plants cells, there may be increased risk of illnesses like cancer and some other undesirable respiratory conditions. A standard regulation will therefore make for proper handling of nanorefrigerants and nanolubricants to guard against any potential risk (i.e. health, environmental, social and speculative) associated with its use. In fact, the UK Royal Society and Royal Academy of Engineers (RS and REA) in their 2004 report called for the improvement of existing regulation because toxicity of chemicals in form of free nanoparticles and nanotube may be unable to be predicted from their toxicity in a larger form and in some cases, could be more toxic than the same mass of the same chemical in larger form.

Possible areas of nanorefrigerant and nanolubricant regulation is in their preparation and packaging. These areas are not quite accommodated in the existing refrigerants regulation. Nano particles sizes are generally smaller than cement dust and possibly atmospheric dust particles. Safety of the person preparing it and that of persons around there must be considered. A regulation enforcing safe preparation methods is therefore required. This regulation should be able to address, for instance, preparation space facilities and ventilation requirements, dress code into such space and its location. This is essential considering nanoparticles sizes and their possible long suspension in the atmosphere if they escape. It is also important to specify the maximum allowable concentration of nanoparticle per unit volume or mass of base refrigerant. At present, harmful substances that could be inhaled are handled in fume chambers. However, with nanoparticles, the extractors may require fitting with very fine 
particulate filters to ensure that nanoparticles do not escape and find their way into the surrounding environment, since some of them may have adverse environmental effect as shown by Barker and Branch (2008) who observed that nanoparticles of titanium dioxide, $\mathrm{TiO}_{2}$, and zinc oxide, $\mathrm{ZnO}$, used in some sunscreen formulations promote photocatalytically initiated, free-radical degradation of prepainted steel sheets installed in roofing applications, thus leading to their unsightly appearance, and Allen et al (2004) who outlined how particle size, different surface treatments and dispersion of several nano and pigmentary grades of titania particles affect the degradation and stabilization of polymers and coatings. Just like in the cosmetics industry, a regulation is required to compel manufacturers of nanorefrigerants or nanolubricants to clearly specify on the refrigerant or lubricant container information like physicochemical specifications, toxicological profile, safety assessment and exposure conditions as well as the nanoparticle and quantity used. Systems running on nanorefrigerant/nanolubricant should also have the nanoparticles type, its concentration and the service/repair guidelines clearly spelt out. Disposal of nanoparticles is another area that needs regulation to ensure proper containment of the nanomaterials. While these may be in the short term, regulation that will make for much safer use of nanorefrigerants and lubricants should target improved refrigerating/heat pumping equipment with, for instance, minimal leak potentials.

\section{CONCLUSION}

Application of nanotechnology in the refrigeration industry is a new and developing area and has the potentials of substantially increasing the COP of the refrigerating and air conditioning machines as well as reduce their bulk. However, some studies conducted point to the fact that nanoparticles may have some undesirable health consequences. Based on those, some level of caution should be applied when adopting nanotechnology. While argument in some quarters continue whether nanotechnology requires regulation or not, it is important to bear in mind that prevention is better than cure. Regulation cannot reduce the benefits or progression of nanotechnology, rather it will make for its more responsible application. While waiting for further studies to fully ascertain the possible medical and environmental consequences of nanorefrigerants and nanolubricants, drawing from existing information on nanoparticles and the regular refrigerants to create policies or amend existing ones could be a proactive measure against any undesirable health and environmental implications of nanotechnology application in the refrigeration/air conditioning industry.

Nanorefrigerants are currently at the developmental state, as such further studies are therefore needed before they can become fully acceptable. Such studies should not just concentrate on the technological potentials but also on health and environmental consequences. At present, available information on health and environmental effects is on the respective nanoparticles. When they are used to produce nanorefrigerants, it is also important to check if there are changes to the chemical and possibly reactive properties of the new fluid. During operation of a typical cooling system, the refrigerant undergoes successive evaporation and condensation. Does the fluid remain homogeneous during this process? Answer to this question will make it easier to work out the safest method of decommissioning a cooling plant and the subsequent disposal of the component parts. Since it has been established that these nanoparticles have undesirable health and environmental effects, further studies should aim at establishing the safe exposure limit of these nanoparticles. These will help to come up with adequate regulatory framework for the safe and responsible application of nanotechnology in the refrigeration industry.

\section{ACKNOWLEDGEMENT}

The authors wish to acknowledge the funding provided by the European Commission under its Horizon 2020 Marie Skłodowska-Curie Actions Individual Fellowship award for 2014.

\section{REFERENCES}

Akhavan-Behabadi, M.A., Sadoughi, M.K., Darzi, M. and Fakoor-Pakdaman, M. (2015). Experimental study on heat transfer characteristics of $\mathrm{R} 600 \mathrm{a} / \mathrm{POE} / \mathrm{CuO}$ nano-refrigerant flow condensation. Experimental Thermal and Fluid Science, 66, pp.46-52.

Alawi, O.A., Sidik, N.A.C. and Mohammed, H.A. (2014). A comprehensive review of fundamentals, preparation and applications of nanorefrigerants. International Communications in Heat and Mass Transfer, 54, pp. 81 - 95.

Allen, N.S., Edge, M., Ortega, A., Sandoval, G., Liauw, C.M., Verran, J., Stratton, J., McIntyre, R.B. (2004). Degradation and stabilisation of polymers and coatings: nano versus pigmentary titania particles. Polymer Degradation and Stability, vol. 85, pp. 927 - 946.

Arul, P.F., Babu, G.J.D., Lavanya, M., Vidhya, S.K., and Devasena, T. (2011). Toxicity studies of Aluminium Oxide Nanoparticles in cell lines. Int. Journal of Nanotechnology and Applications, 5(2), pp. 99 - 107. 
Barker, P.J. and Branch, A. (2008). The interaction of modern sunscreen formulations with surface coatings. Progress in Organic Coatings, vol. 62, pp. 313 - 320.

Bi, S., Guo,K., Liu,Z. and Wu, J.(2011). Performance of a domestic refrigerator using TiO2-R600a nano-refrigerant as working fluid. Energy Conversion and Management, 52, pp. 733 - 737.

Boyles, M.S.P., Ranninger, C., Reischl, R., Rurik, M., Tessadri, R., Kohlbacher, O., Duschl, A. and Huber, C.G. (2016). Copper oxide nanoparticle toxicity profiling using untargeted metabolomics. Particles and Fibre Toxicology, 13:49 DOI 10.1186/s12989-016-0160-6.

Burklew, C.E., Ashlock, J., Winfrey, W.B. and Zhang, B. (2012). Effect of Aluminium Oxide Nanoparticle on the growth, development and microRNA expression of tobacco (Nicotiana tabacum). PLoS ONE, 7(5), e34783. doi:10.1371/journal.pone.0034783

Chau, C., Wu, S., and Yen, G. (2007). The development of regulations for food nanotechnology Trends in Food Science \& Technology, 18, $269-280$.

Christian, P., et al. (2008). Nanoparticles: structure, properties, preparation and behaviour in environmental media. Ecotoxicology, vol. 17, pp. 326-343.

Coumaressin, T. and Palaniradja, K. (2014). Performance Analysis of a Refrigeration System Using Nano Fluid. International Journal of Advanced Mechanical Engineering, 4(4), pp. 459 - 470.

Cushen, M., Kerry, J., Morris, M., Cruz-Romero, M. and Cummins, E. (2012). Nanotechnologies

in the food industry e Recent developments, risks and regulation. Trends in Food Science \& Technology, 24, pp. 30 46.

Environews. Particles in Practice: How Ultrafines Disseminate in the Body. Environmental Health Perspectives, Vol. 113, No. 11, November 2005, pp. A758 - A760.

Environmental Investigation Agency. EU F-Gas Regulation Handbook: Keeping Ahead of the Curve as Europe Phases Down HFCs. September 2015.

Environmental Protection Agency. Section 608 of Clean Air Act: Stationary Refrigeration and Air Conditioning, 430-F-10040.

Gibbs, L. and Tang, M. Nanotechnology: Safety and Risk Management Overview. NNIN Nanotechnology Safety Workshop, Georgia Institute of Technology, 2 Dec 2004.

Gustavsson, P., Hedmer, M. and Rissler, J. Carbon nanotubes - Exposure, toxicology and protective measures in the work environment. Kunskapsöversikt, Rapport 2011:1. www.av.se/publikationer/rapporter/

Henderson, K., Park, Y., Liu, L., Jacobi, A.M., (2010). Flow-boiling heat transfer of R-134a-based nanofluids in a horizontal tube. Int. J. Heat Mass Transf., 53, pp. 944-951.

HSE - Health \& Safety Executive - (2004). Nanotechnology information sheet - HSIN1. Available from http://www.hse.gov.uk/pubns/hsin1.pdf

HSE - Health and Safety Executive - (2006). Review of the adequacy of current regulatory regimes to secure effective regulation of nanoparticles created by nanotechnology. Available from http://www.hse.gov.uk/horizons/nanotech

IFST - Institute of Food Science and Technology - (2006). Nanotechnology. Available from http://www.ifst.org/uploadedfiles/cms/store/ATTACHMENTS/Nanotechnology.pdf

Jiang, W., Ding, G., Peng, H., Gao, Y. and Wang, K. (2009). Experimental and Model Research on Nanorefrigerant Thermal Conductivity. HV AC\&R Research, Vol 15, No. 3, pp. 651 - 669.

Jiang, W., Ding, G., Peng, H., (2009). Measurement and model on thermal conductivities of carbon nanotube nanorefrigerants. Int. J. Therm. Sci., 48, pp. 1108-1115.

Karlsson, H.L., Cronholm, P., Gustafsson, J. and Möller, L. (2008). Copper oxide nanoparticles are highly toxic: a comparison between metal oxide nanoparticles and carbon nanotubes. Chemical Research in Toxicology, 21(9), pp. $1726-1732$.

Kim, H., Liu, X., Kobayashi, T., Kohyama, T., Wen, F., Romberger, D.J., Conner, H., Gilmour, P.S., Donaldson, K., MacNee, W. and Rennard, S.I. (2003). Ultrafine carbon black particles inhibit human lung fibroblastmediated collagen gel contraction. American Journal of Respiratory Cell and Molecular Biology, vol. 28, pp. 111-121.

Kreilgaard, M. (2002). Influence of microemulsions on cutaneous drug delivery. Advanced Drug Delivery Reviews, 54, pp. S77 - S98.

Maxwell, J.C. Treatise on Electricity and Magnetism, Clarendon Press, Oxford, UK, 1873.

Moe, J., Thompson, M. and Bakkum, B. HVAC Refrigerants: A Balanced Approach. Trane Engineers Newsletter volume 40-2, ADM-APN041-EN, June 2011.

National Institute of Environmental Health Sciences Community Outreach and Education Programme. Particles: "Size Makes All the Difference". (http://www.niehs.nih.gov/health/assets/docs_a_e/ehp_student_edition_lesson_particles_size_makes_all_the_difference.pdf :accessed on May 30, 2016)

Nair, V., Tailor, P.R. and Parekh, A.D. (2016). Nanorefrigerants: A comprehensive review on its past, present and future. International Journal of Refrigeration, vol. 67, pp. 290 - 307. 
National Nanotechnology Initiative. Supplement to the President's Budget For Fiscal Year 2016, March 2015.

Nel, A., Xia, T., Madler, L., and Li, N. (2006). Toxic potential of materials at the nanolevel. Science, vol. 311, pp. 622 627.

Noor, H., Yap, C.L., Zolkepli, O. and Faridah, M. (2000). Effect of Exposure to Dust on Lung Function of Cement Factory Workers. Med J Malaysia, Vol 55, No 1, pp. 51 - 57.

Oberdörster, G., Maynard, A., Donaldson, K., Castranova, V., Fitzpatrick, J., Ausman, K., Carter, J., Karn, B., Kreyling, W., Lai, D., Olin, S., Monteiro-Riviere, N., Warheit, D. and Yang, H. (2005). Principles for characterizing the potential human health effects from exposure to nanomaterials: elements of a screening strategy. Particle and Fibre Toxicology, 2:8, Available from http://www.particleandfibretoxicology.com/content/2/1/8.

Peng, H., Ding, G., Hu, H. and Jiang, W. (2010). Influence of carbon nanotubes on nucleate pool boiling heat transfer characteristics of refrigerant-oil mixture. Int. J. Therm. Sci., 49, pp. 2428-2438.

Poland, C.A., et al. (2008). Carbon nanotubes introduced into the abdominal cavity of mice show asbestos-like pathogenicity in a pilot study. Nature Nanote $\neg$ chnology, vol. 3, pp. $423-428$.

Roco, M. National Nanotechnology Initiative in the International Context. The Tenth International Nanotechnology Conference on Communication and Cooperation (INC 10), National Institute of Standards and Technology (NIST), Gaithersburg, Maryland, May 13-15, 2014.

Tsuji, J.S., Maynard, A.D., Howard, P.C., James, J.T., Lam, C.W., Warheit, D.B. and Santamaria, A.B. (2006). Research strategies for safety evaluation of nanomaterials, part IV: risk assessment of nanoparticles. Toxicol Sci. 89(1): pp. 42-50.

Senjen, R. Nanomaterials - Health and Environmental Concern. Nanotechnologies in the 21st Century (Ed: Hontelez, J.), Issue 2, 2009. (Available at: http://eeb.org/publication/ general.html)

Sweet, L and Strohm, B. (2006). Nanotechnology—Life-Cycle Risk Management. Human and Ecological Risk Assessment 12(3):528-551.

Salamanca-Buentello F., Persad D.L., Court E.B., Martin D.K., Daar A.S., and Singer, P.A. (2005). Nanotechnology and the developing world. PLoS Medicine, 2(4): e97.

Sidik, N.A.C., Mohammed, H.A., Alawi, O.A. and Samion, S. (2014). A review on preparation methods and challenges of nanofluids. International Communications in Heat and Mass Transfer, 54, pp. 115 - 125.

Soliman, A. The Need for Stronger Nanotechnology Regulation. Food Safety News, OCTOBER 16, 2012. Available from: $\quad$ http://www.foodsafetynews.com/2012/10/why-we-should-have-more-regulations-onnanotechnology/\#.V2FmOigrLb0 (accessed: June 15, 2016).

Subramani, N. and Prakash, M.J. (2011). Experimental studies on a vapour compression system using Nanorefrigerants. International Journal of Engineering, Science and Technology Vol. 3, No. 9, pp. 95 -102.

Subramani, N., Mohan, A. and Prakash, J.M. (2013). Performance studies on a vapour compression refrigeration system using nano-lubricant. IJIRSET, Vol. 2, Special Issue 1, pp. $522-530$.

Sun, B., Yang, D., 2013. Experimental study on the heat transfer characteristics of nanorefrigerants in an internal thread copper tube. Int. J. Heat Mass Transf., 64, pp. 559-566.

Wakefield, G., Green, M., Lipscomb, S., \& Flutter, B. (2004). Modified titania nanomaterials for sunscreen applications - reducing free radical generation and DNA damage. Materials Science and Technology, vol. 20, pp.985 $-988$.

Yang, L., Du, K., Bao, S. and Wu, Y. (2012). Investigations of selection of nanofluid applied to the ammonia absorption refrigeration system. International Journal of Refrigeration, 35, pp. $2248-2260$.

Yang, D., Sun, B., Li, H. and Fan, X. (2015). Experimental study on the heat transfer and flow characteristics of nanorefrigerants inside a corrugated tube. International Journal of Refrigeration, 56, pp. $213-223$. 